\title{
Effect of Non Performing Loans on Profitability of the Banking Industry in Kenya
}

\author{
Harwood Kajirwa Isabwa, Martin Wekesa Mabonga \\ Department of Economics, Accounts \& Finance, Jomo Kenyatta University of Science \& Agriculture, Nairobi, Kenya \\ Email address: \\ harwoodisabwa@yahoo.com (H. K. Isabwa), martinmabonga254@gmail.com (M. W. Mabonga) \\ To cite this article: \\ Harwood Kajirwa Isabwa, Martin Wekesa Mabonga. Effect of Non Performing Loans on Profitability of the Banking Industry in Kenya. \\ International Journal of Finance and Banking Research. Vol. 6, No. 2, 2020, pp. 28-36. doi: 10.11648/j.ijfbr.20200602.12
}

Received: March 23, 2020; Accepted: April 10, 2020; Published: April 30, 2020

\begin{abstract}
Upsurge in the rate of non - performing loans in the Kenyan banking industry warranted a study to find out its effect on the profitability of the whole banking industry. The main objective of the study was to determine the effect of non performing loans on the profitability of the banking industry in Kenya. A positivism research philosophy was adopted. The study used cross sectional and time series designs. Panel data about the Kenyan banking industry as a whole was incorporated in the study. Statistical package of social studies version 24.0 aided in data analysis. Pearson correlation and regression inferential statistical techniques were used in the study. The study found a strong negative relationship between nonperforming loans and profit after tax $\left(\mathrm{r}=-.754^{* *}, \mathrm{p}\right.$ value $\left.<.01\right)$. Non - performing loans had a significant negative effect on profitability of the Kenyan banking industry $(\beta=-.754, p=007, \alpha<0.01)$. The value of adjusted R-square is 0.521 implying that $52.1 \%$ of total variation of profitability of the Kenyan banking industry is explained collectively by nonperforming loans. The study concluded that non- performing loans has a negative significant effect on profitability of the Kenyan banking industry. In order to hedge against upsurge in the rate of non - performing loans the banking industry should enforce effective regulation, create awareness, and curb unproductive borrowings. There must be multiple level of approval to sanction huge loans. Moreover, there should be transparent mechanism and proper disclosure regulation.
\end{abstract}

Keywords: Non-performing Loans, Central Bank of Kenya, Profitability, Profit After Tax, Kenya

\section{Introduction}

Loans form a major component of Banks balance sheet and any change in its composition affects the entire structure. Nonperforming loans are those loans that are not being serviced as per the loans contracts and expose the banks to potential losses [1]. Loan delinquency must be minimized by Banks at all cost. There should be a continuous review of individual exposures in order to monitor loan quality and reduce losses. Effective credit risk management of financial institutions is largely reflected in the proportion of NPL's loans to gross loans. Nonperforming loans can be measured either by the ratio of nonperforming loans ratio and/or non performing loans coverage ratio. Non performing coverage ratio refers to the ratio of allowance for probable losses on nonperforming loans to total nonperforming loans and it is computed as follows: Provisions for losses on non performing loans over non performing loans. NPL ratio refers to the ratio of nonperforming loans to total loans i.e. gross of allowance for probable losses. It is measured as non performing loans over total loans and advances.

In this study the ratio of nonperforming loans to total gross loans was adopted to assess the effect of nonperforming loans on profitability of the Kenyan Banking industry. Nonperforming loans are closely associated with banking crises. The Japanese economy suffered financial crisis in 2002 which was linked to non performing loans. Thousands of billions of yens of bad loans were recorded as a result of collapse in asset prices more than a decade ago in the country's financial system [26]. United States of America Bank in Port Chester reported larger losses last quarter of 2008 in the face of flat revenue and a sharply larger portfolio of bad loans. The bank had 10 nonperforming loans that was valued at \$11.9 million by the end of last quarter, up from $\$ 3.7$ million a year earlier. The loans represented 7.3 percent of the bank's loan portfolio, according to the banks president and chief executive officer Ronald gentile, the collateral underlying the bad loans exceeded their outstanding balance, however, the bank 
increased its loan-loss provision to $\$ 2.41$ million, up 46 percent from a year earlier. Most of the troubled loans were for house construction and other land development. Loans that were past due 30 through 89 days rose sevenfold year over year, to $\$ 21.1$ million, according to a bank filing with regulators [13].

Increase in the rate of non-performing loans continues to be an issue of major supervisory concern in Kenya. The level of non-performing loans has been increasing steadily [9]. These loans have made some banks to fall into liquidation and closure. [23] posits that one of the greatest challenges facing commercial banks in Kenya today is how to deal with the growing portfolio of bad debts. The rate of nonperforming loans is weighted against the total portfolio of all loans and advances that the bank has extended in order to obtain its magnitude. A high ratio of non-performing loans to gross nonperforming loans implies imprudent poor credit management and lending practice. A low ratio of nonperforming loans is therefore desirable as it poses a threat to customer's deposits.

Commercial banks in Kenya recorded Sh63 billion in nonperforming loans in the last financial year owing to poor performance by manufacturers and traders during the 2017 general election, which slowed down loan repayments [10]. The value of bad loans was more than 80 per cent of the profit before tax made cumulatively by commercial banks, with the ratio of non-performing loans doubling from six per cent three years ago to 12 per cent. Central Bank of Kenya data indicates non-performing loans went up from Sh234.6 billion in June 2017 to Sh298.4 billion recorded as at June 2018 with the manufacturing, trade and real estate sectors leading in the losses. "During the period under review, eight out of the 11 economic sectors registered increased non-performing loans (NPLs)," explains the CBK in its latest annual report. "The increase in NPLs was mainly caused by delayed payments by government agencies and private sector, business stagnation during the prolonged electioneering period and slow uptake of developed houses in the real estate sector," [10].

The trade sector lead with the number of non-performing loans rising by Sh20 billion last year to Sh88 billion as at June 2018, with the CBK blaming the 2017 poll jitters for the depressed liquidity. The same case was evident in the manufacturing sector where NPLs increased by 62 per cent, up from Sh33 billion in 2017 to Sh51 billion as at June 2018. "The real estate sector, where NPLs increased by Sh14.4 billion (48 per cent) as a result of slow uptake of developed housing units, and delay in subdivision of land," [9]. This has since seen the ratio of gross loans to non-performing loans increase from 9.9 per cent in June 2017 to 11.97 per cent in June 2018, with the industry recording sh298 billion cumulatively in NPLs. Incongruence in findings exists among the few studies that have been done on the effect of nonperforming loans on profitability of banking industry in Kenya.

Researchers (such as: [21, 6]) found that nonperforming loans has a negative effect on profitability while [28] found that non performing loans had no effect on banks profitability. This incongruence in findings warranted a further research to find out the effect of nonperforming loans on profitability of banking industry in Kenya. Profit after tax as a measure of profitability was not used as a proxy of profitability in majority of the studies and hence the knowledge gap that the current study sought to fill.

\subsection{Banking Industry in Kenya}

The banking industry in Kenya is regulated and governed by the Companies Act, the Central Bank of Kenya Act and the Banking Act. These Acts are used together with the prudential guidelines which Central bank of Kenya issues from time to time. Central Bank of Kenya is tasked with formulating and implementation of monetary and fiscal policies. Central bank is the lender of last resort in Kenya and is the banker to all other banks. The CBK ensures the proper functioning of the Kenyan financial system, the liquidity in the country and the solvency of the Kenya shilling. Central bank of Kenya falls under the Ministry of finance.

The banking sector is made up of 43 commercial banks, 13 microfinance institutions, 1 mortgage finance company, 19 money remittance providers, 9 representative offices of foreign banks, 3 credit reference bureaus and 73 foreign exchange bureaus. Out of the 43 commercial banks only 11 are listed on the Nairobi securities exchange. Commercial banks are categorized into three tiers I, II and III [10]. The banking sector has experienced a myriad of challenges in the recent past which led to closure of commercial banks such as Imperial bank, Dubai bank while chase bank has been put under receivership.

S\&P Global Ratings has positioned Kenya's banking industry at high risk due to its shrinking banking performance as well as dropping wealth levels. Credit risk in the economy is a key weakness because of the very weak payment culture and rule of law, weak underwriting standards, high degree of credit concentrations, and high level of foreign currency lending," the report stated. Kenya was ranked at category 9 along Tunisia, Turkey, Uzbekistan, Cambodia, Vietnam besides Nigeria which was ranked at position 10 in Banking Industry Country risk assessment, which signifies higher risk [24].

\subsection{Scope of the Study}

The study focused on effect of non-performing loans on profitability of the Banking industry in Kenya. Non performing loans to gross loans ratio was used as a proxy of nonperforming loans while profit after tax for profitability. Furtherance of the study was guided by the information asymmetry theory. The study period was between 2008 to 2018. Findings presented are an aggregate of all financial institutions that fall under the Kenyan banking industry. Panel data was extracted from the firms' audited financial statements. The remainder of this article paper is organized as follows. Section 2 covers review of past studies and defines the main hypothesis. Section 3 covers materials and methods. Section 4 covers the results and discussion. Section 5 presents the conclusion and recommendations. 


\section{Literature Review and Hypothesis Development}

\subsection{Nonperforming Loans and Asymmetric Information Theory}

Asymmetric information theory was espoused by [3]. This is a theory relevant for situations where there is imperfect knowledge. In particular it occurs where one party has different information to another. Moral hazard and adverse selection between borrowers and lenders is as a result of one party being in possession of more information than the other. In this regards, the borrowers are aware of projects they intend to invest in than the lenders which results into information advantage [36].

In the debt market, lenders may not be in a position to skew out borrowers who are a good risk or bad risk. This is well expailed by the "lemons" problem. The concept of adverse selection and the "lemons" problem was enunciated for the first time by [8]. Inability to make a distinction between the borrowers that are categorized as good risk or bad risk, the lenders usually calculates a suitable interest rate i.e. an average of both good and bad risk borrowers (lemons). Credit to be extended to borrowers may be rationed as a result of information asymmetry. In some instances some borrowers end up being denied access to credit facility due to reduction in the loan amount to be extended to borrowers [31]. In addition to credit rationing, the interest rate is usually sometimes raised by the financial institutions.

[14] Indicate that a small rise in the riskless interest rate can lead to a very large decrease in lending, and possibly a collapse in the market. Moral hazard relates to a certain party engaging in behaviour that is more risky besides the plans that mitigate a party some risk [36]. The borrowers desire to earn high returns may make them opt for investing in projects that are more risky. The returns they get maynot be intandem with their expectations or the amount of investment made in the projects. To avert this scenario, the financial institutions usually comes up with provisions within loan contracts such as disbursement in increments or conditional on performance todate that hinders borrowers from taking excessive risks that reduces projected cashflows needed to fullfill the periodic loan amortization.

In order to reduce the risk exposure, collateral is needed for an individual to access a loan facility from a financial institution. Transaction costs as a result increases hence limiting the amount of funds an individual can access at any one given point in time. This leads to an increase in firms' financial risk exposure. The amount of debt and dividends issued are the two types of signals investors look for from the managers. Stock prices and leverage have a positive relationship due to positive signalling effect $([15,32,5])$. During leverage, insiders normally do not sell their shares hence increase in exchange offers [12]. This is because of access to more information on the prospects of the firm.

[18] Opine that debt or outside equity could be used to ellicit accurate information about the value of a firm in alternative uses. The reputation of large firms in the debt market is usually better and the firms level of diversification is high [16]. This makes the firms financial structure to comprise more debt than equity finance. For small firms information asymmetry is a bigger problem than the bigger ones because during loan applications most of the data which they supply to the banks is not readily verifiable. This inturn makes access to debt financing elusive [19].

\subsection{Profitability}

Profitability of the banking sector is a subject that has received a lot of attention in recent years and there is now a large literature which has examined the role played by management of resources in determining bank profitability. Indicators used to measure profitability are many and includes Return on Assets, Return on Equity and Net Interest Margin. There are however divergent views among scholars on the superiority of one indicator over the others as a good measure of profitability. For instance, $[17,37]$ believed that the three indicators are all good namely ROA, ROE and NIM. [20] Used only ROE to measure profitability in the study. [33] Used only the gross profit margin in measuring profitability. [30] Did not believe that profit level perse could constitute a good measure of profitability and therefore used ROA and ROE.

[37] Believed that the three indicators are all good namely ROA, ROE and NIM. [2] Identified the three indicators, namely: Net Interest Margin (NIM), Return on Assets (ROA) and Return on Equity (ROE) to be widely employed in the literature to measure profitability. Profitability connotes a situation where the income generated during a given period exceeds the expenses incurred over the same length of time for the sole purpose of generating income [34]. The fundamental requirements here are that the income and the expenses must occur during the same period of time using the Matching Concept and the income must be a direct consequence of the expenses. The period of time may be one week, three months, one year etc [33].

It is not immaterial whether or not the income has been received in cash nor is it compulsory that the expenses must have been paid in cash. For a profit-oriented organization, profit is the soul of business. A company remains in operation because it expects to make profits. Once that expectation is confirmed unattainable, the most rational decision is to close shop or exit the business. According to [4] profitability measures include Profit before Tax (PBT), Profit after Tax (PAT), ROE, Rate of Return on Capital (ROC) and ROA. [34] used Earnings per Share (EPS). The current study adopted profit after tax as recommended by [4] as an optimal measure of profitability.

\subsection{Nonperforming Loans and Profitability}

A study was conducted by [6] on the impact of profitability on quantum of non-performing loans in Pakistan Banks. Panel data of sixteen Pakistan banks were considered between 2006 to 2012. Three models were adopted to check the relationship between profitability and nonperforming loans. Model one represented return on asset as dependent variable while nonperforming loans were taken as independent variable. Model two represented Return on Equity as dependent variable while nonperforming loans 
were taken as independent variable. Model three represented Stock Return as dependent variable while non-performing loans were taken as independent variable. The study findings revealed that nonperforming loans have a negative effect on return on assets and return on equity. Nonperforming loans had no significant relationship with stock returns.

[1] Researched on the influence of credit risk on performance of five banks in Nigeria. The study period was between 2000 and 2010. The ratio of nonperforming loans to loans plus advances, total loans to advances plus deposits and ratio of loan loss provisions was used as proxies of nonperforming loans. Performance was measured by return on assets. Fixed effect model was used in the study and according to results of regression analysis, non-performing loans and loan losses provisions are adversely affecting the performance while total loans to advance plus deposit ratio has positive significant effect on the performance.

[21] Analyzed the effect of credit risk on banks' performance in Tanzania. The proxies of credit risk were; ratios of nonperforming loan, loan loss to gross loan, loan loss to net loan and impaired loan to gross loan. Return on assets was used as a proxy for banks performance. Effect of deposits and bank size was controlled in the study. The sample size was 11 banks in Tanzania. The study found that the ratios of nonperforming loans, loan loss to gross loan, loan loss to net loan have significant negative influence on banks' performance. [22] Researched on credit risk management and profitability of commercial banks in Kenya. The ratio of nonperforming loans to total loans was used as the proxy for nonperforming loans and profitability was measured using return on total assets. Panel data for the period between 2004 to 2008 was collected. The study findings revealed that the bulk of the profits of commercial banks are not influenced by the amount of credit and nonperforming loans suggesting that other variables other than credit and nonperforming loans impact on profits. The results indicated that there is no relationship between profits, amount of credit and the level of nonperforming loans. Profit after tax was not used as a measure of profitability which the current study incorporated.

[29] Examined the effect of non-performing loans on financial performance of deposit taking micro finance institutions in Kenya. The study made use of secondary data that was obtained specifically from the financial stations of the microfinance institutions. The study found out that non performing loan in deposit taking microfinance institutions account for the greatest percentage of the variance in the profitability of the institutions. Also, [28] researched on the relationship between the level of nonperforming Loans and the financial performance of commercial banks in Kenya. Multi linear analytical model was used to determine the relationship between the NPLs and the financial performance of commercial banks. The relationship between these ' bad loans" and the financial performance represented by ROA was regressed. The results indicated that there was no relationship between profits and the level of non-performing loans. The study however did not consider profit after tax as a measure of financial performance of commercial banks.
The literature reviewed led to the formulation of the following hypothesis statement:

$H_{0} 1$ : Non performing loans has no significant effect of profitability of the banking industry

\section{Materials \& Methods}

Research philosophy can simply be defined as a belief about the way in which data about a phenomenon should be gathered, analyzed and used [11]. For this study, a positivism research philosophy was adopted. The choice for the positivism research philosophy is supported by the principle underlying this philosophy. According to the principles of positivism, the philosophy depends on quantifiable observations that lead themselves to statistical analysis [25]. It is noted that positivism is in accordance with the empiricist view that knowledge stems from human experience [35]. This principle conforms to the nature of the study in that it deals with the quantifiable observations. With regard to the progression of this study, it was guided by the hypothesis in attempt to show the association between independent variable and dependent variable. All these attributes of the study apply for the positivism research philosophy hence its choice as the ideal research philosophy.

This study used cross sectional and time series designs because the current study used panel data. This research design is suitable for the study as it deals with the observations on the same subjects in different times. Panel data was employed because it helps to study the behavior of each bank over time and across space [7]. Panel data allows for the use of existing data that has been recorded for any time period. The study period under consideration is between 2008 to 2018 . The study targeted the Kenyan banking industry as a whole. Data was drawn from the annual reports of central bank of Kenya. The study used Karl Pearson product moment correlation analysis to assess the nature of relationship between the dependent variable (PAT) and the independent variable (Non performing loans). The ratio of nonperforming loans to gross loans was used as a proxy for non performing loans. The correlation coefficient value (r) ranging from 0.10 to 0.29 is considered weak, from 0.30 to 0.49 is considered medium and from 0.60 to 1.0 is considered strong [28]. Regression analysis was used to identify the extent to which nonperforming loans to gross loans affects profitability at $99 \%$ confidence level. The panel regression model was as follows: $Y_{i t}=\beta_{0}+\beta_{1} x_{1 i t}+e_{i t}$

Where; $\mathrm{Y}_{\mathrm{it}}=$ Profit after Tax, $\mathrm{X}_{1 \mathrm{it}}=$ Ratio of nonperforming loans to gross loans; $\mathrm{e}_{\mathrm{it}}=$ error term; $\beta_{0}=$ intercept; $\beta_{1},=$ coefficient of $x_{1}$.

\section{Results \& Discussion}

Trend lines were drawn to determine the variations in nonperforming loans and profit after tax between 2008 and 2018. During coding of the data in SPSS, 1 represented the percentage of the ratio of non-performing loans to gross loan between ( $1 \%$ to $3 \%), 2$ (3\% to $6 \%), 3(6 \%-9 \%)$ and $4(9-$ $12 \%)$. Figure 1 presents the findings of non - performing 
loans and profit after tax over a period of 11 years. In 2008 the ratio of nonperforming loans to gross loans was the highest at 4 . This was a decline from $15.1 \%$ in 2007 which was attributed to write-offs and recoveries by some institutions. The ratio of nonperforming loans to gross loans decreased to 3 in 2009 largely due to enhanced credit underwriting standards applied by financial institutions. It remained constant at 3 in 2010. This was attributable largely due to enhanced credit underwriting standards applied by financial institutions. In 2011 it decreased further to 2 due to continued deployment of enhanced appraisal standards by the financial institutions.

Non-performing loans increased to 3 in 2012 and decreased to 2 in 2013. The increase in NPLs is attributed to high interest rates and reduced economic activities during the period towards and after the March 2013 general elections. It decreased to 2 in 2014. It remained constant at 2 until 2016 due to continued deployment of enhanced appraisal standards by banks. Increased to 3 in 2017 because Banks downgraded loan accounts due to delayed payments by private and public sector entities, challenges in the business environment and low business turnovers and finally increased to 4 in 2018. The increase in NPLs was mainly caused by delayed payments by government agencies and private sector, business stagnation during the prolonged electioneering period, and slow uptake of developed houses in the real estate sector. The above reasons led to downgrading of loan accounts by banks, which impacted negatively on the quality of assets.

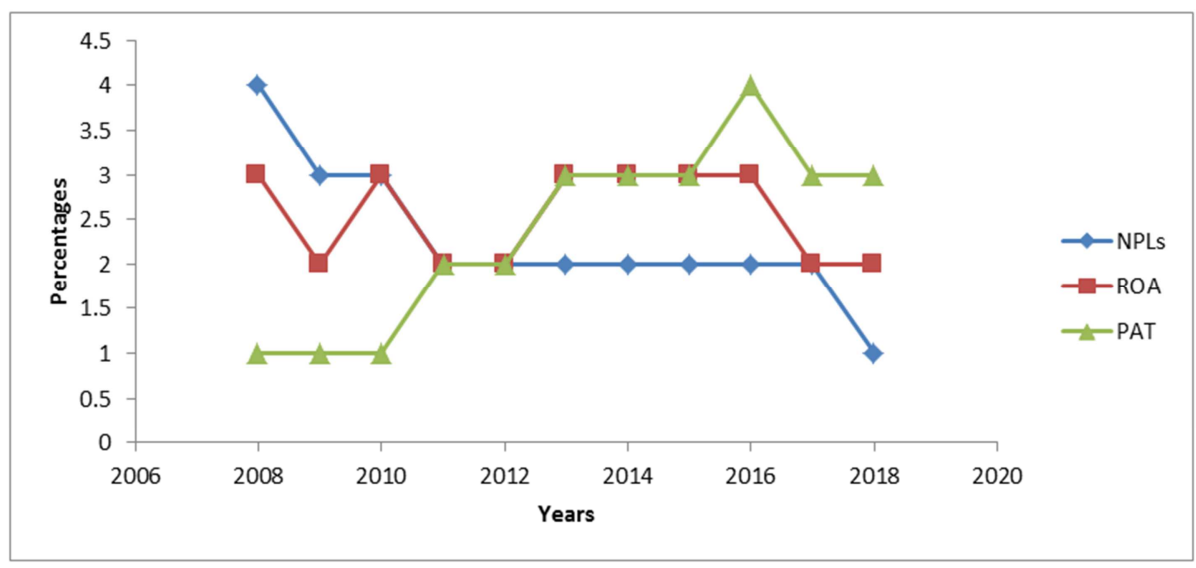

Figure 1. Trend of non-performing loans, profit after tax and return on assets.

Data on profit after tax was represented in percentage form. Data coding in SPSS was undertaken, 1 represented the percentage of profit after tax between (20\% to $40 \%), 2(40 \%$ to $60 \%), 3(60 \%$ to $80 \%)$ and $4(80 \%-100 \%)$. The results are as presented in Figure 1. In 2008 the profit after tax in percentage form was between $20 \%$ to $40 \%$ (1), it remained at (1) until 2010. It increased to $2(40 \%$ to $60 \%)$ in 2011 and remained at 2 in 2012. It increased to 3 in 2013 and remained at 3 until 2015. In 2016 it increased to 4 and decreased to 3 in 2017. Finally, in 2018 the profit after tax of the Kenya banking industry was the same the one for 2017. In regards to return on assets, in 2008 it was at 3 and it decreased to 2 in 2009. In 2010 it increased back to 3 and decreased to 2 in
2011. In 2012 it remained at 2 and increased back to 3 in 2013. The value remained at 3 until 2016. Return on assets reduced to 2 in 2017 and remained at 2 in 2018.

The results of Karl Pearson correlation revealed that there was a strong negative relationship between nonperforming loans and profit after tax $\left(r=-.754^{* *}, \mathrm{p}\right.$ value $\left.<.01\right)$. This implies that the proportion of nonperforming loans to gross loans has an inverse relationship with profitability as proxied by profit after tax. In regards to non performing loans and return on assets, there was a weak positive relationship between non performing loans and return on assets $(\mathrm{r}=.332 *$, $\mathrm{p}$ value $>.05$ ) as shown below in Table 1 :

Table 1. Correlations Statistics.

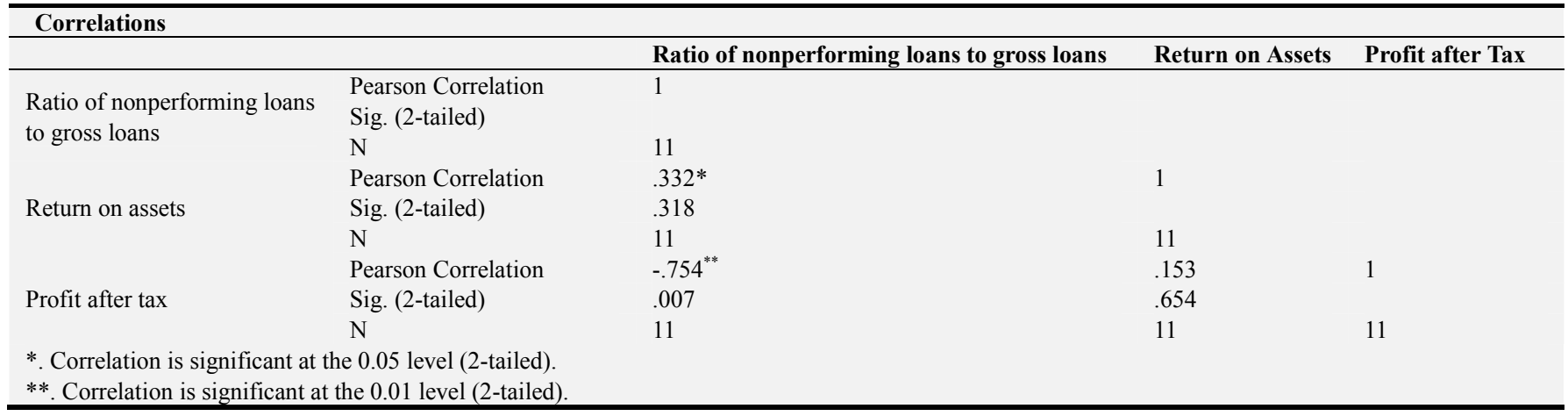

Source: Survey data, 2020. 


\section{Regression analysis}

Simple linear regression model was used to predict profitability in the study. The prediction was carried out basing on the effect of nonperforming loans on profitability of banking industry in Kenya. Simple linear regression analysis is a powerful technique used for predicting the unknown value of a variable from known value of a variable also called the predictor [27].

Test of Regression Analysis Assumptions

The regression model is based on several assumptions; linearity of residuals, normality of residuals, auto correlation of residuals and homoscedasticity. Scatter plot was used to test linearity of residuals. A scatter plot of residuals and y values was drawn. ZRESID values were recorded on the vertical axis and ZPRED plotted on the horizontal axis. If the scatter plot follows a linear pattern, not a curvilinear pattern that shows that linearity assumption is met [27]. The linearity assumption was upheld in this study as the residual points followed a linear pattern and not a curvilinear pattern as shown in the figure below:

\section{Scatterplot}

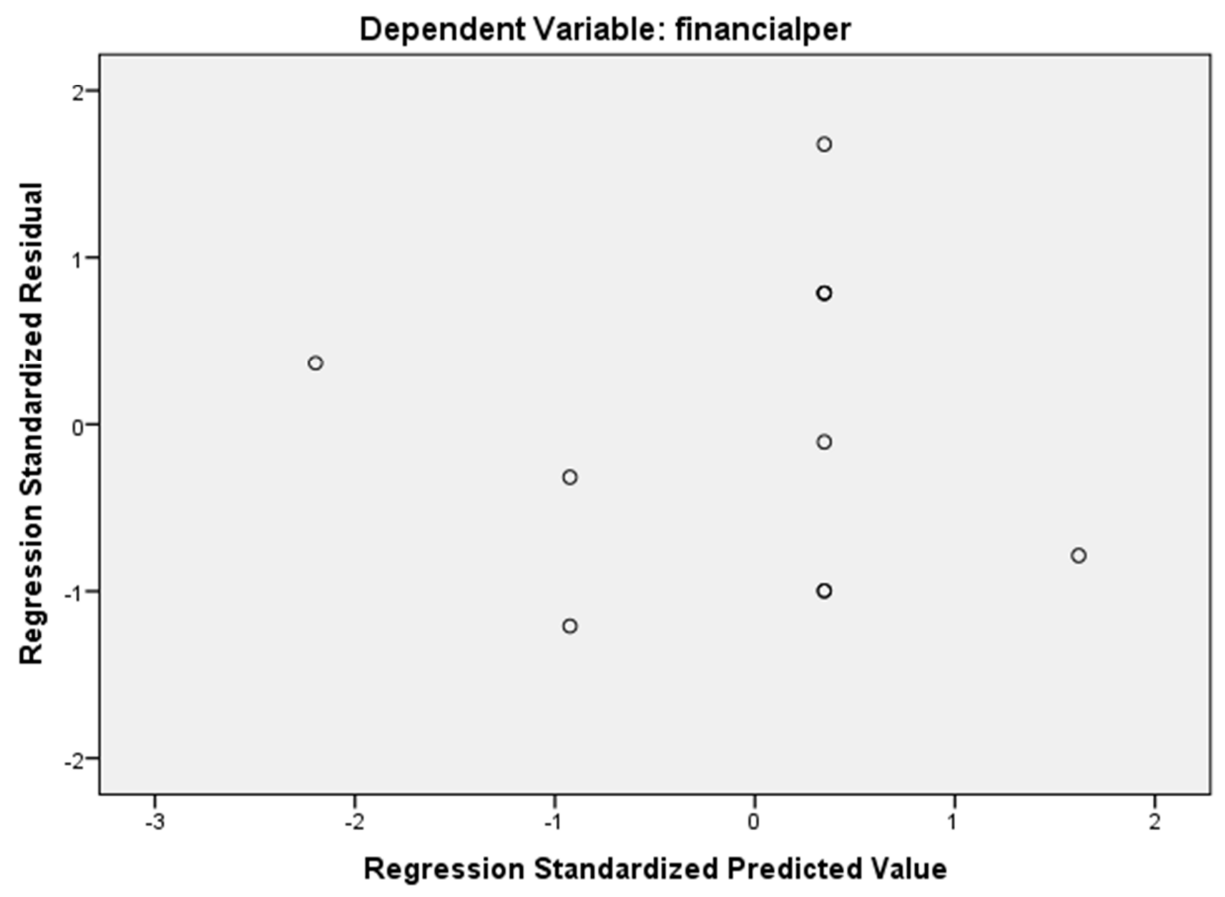

Source: Survey data, 2020.

Figure 2. Scatter plot for test of Linearity.

In regards to normality of residuals, it implies that residuals are normally distributed. Kolmogorov - smirnov and Shapiro wilk test were conducted. The former is suitable for large samples while the latter for small samples. A p - value greater than 0.01 means that the residuals are normally distributed [27]. Shapiro - wilk has a p value of.241 implying that in this study the residuals were normally distributed.

Table 2. Test of Normality of Residuals.

\begin{tabular}{|c|c|c|c|c|c|c|}
\hline \multicolumn{7}{|l|}{ Tests of Normality } \\
\hline & \multicolumn{3}{|c|}{ Kolmogorov-Smirnov $^{\mathrm{a}}$} & \multicolumn{3}{|c|}{ Shapiro-Wilk } \\
\hline & Statistic & Df & Sig. & Statistic & Df & Sig. \\
\hline $\begin{array}{l}\text { Financial performance } \\
\text { a. Lilliefors Significance Correction }\end{array}$ & .439 & 35 & .154 & .606 & 35 & .241 \\
\hline
\end{tabular}

Source: Survey data, 2020.

Auto correlation among study variables means that successive observations of the dependent variable are not correlated. This indicates that successive residuals have no pattern and are not highly correlated and there are no long runs of positive or negative residuals [35]. The DurbinWatson's $d$ tests the null hypothesis that the residuals are not linearly auto correlated [25]. While d can assume values between 0 and 4, values around 2 indicate no autocorrelation. As a rule of thumb values of $1.5<\mathrm{d}<2.5$ show that there is no auto-correlation in the data [35]. The value of Durbin Watson was at 1.265 which indicates no autocorrelation among the variables as shown in Table 3: 
Table 3. Auto correlation.

\begin{tabular}{llllll}
\hline Model & R & R Square & Adjusted R Square & Std. Error of the Estimate & Durbin-Watson \\
\hline 1 & $.492^{\mathrm{a}}$ & .242 & .158 & 1.12022 & 1.265 \\
a. Predictors: (Constant), ratio of nonperforming loans to gross loans & & \\
b. Dependent Variable: Financial performance & & & \\
\hline
\end{tabular}

Source: Survey data, 2020.

Homoscedasticity assumption implies that the variation in the residuals is the same for both large and small values of the predicted value of the dependent variable [25]. A scatter plot of residuals and $y$ values was drawn. ZRESID values were plotted on the vertical axis, and ZPRED were plotted on the horizontal axis. If the residuals do not fan out in a triangular fashion that means that the homoscedasticity assumption is met. The figure below shows that the residuals are not in a triangular fashion which implied that the homoscedasticity assumption was upheld.

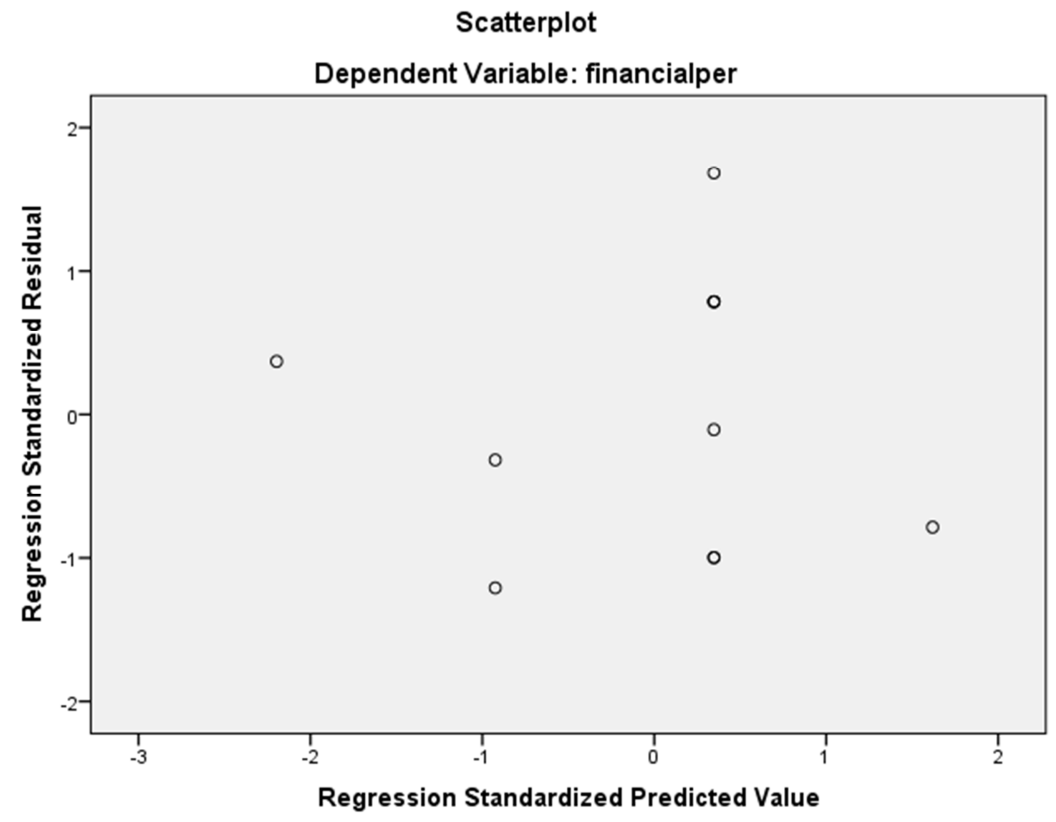

Source: Survey data, 2020.

Figure 3. Test of Homoscedasticity.

Test of significance of the Model

Analysis of variance was employed to test the significance of the regression model. The results are shown in the Table 4.

Table 4. ANOVA.

\begin{tabular}{llllll}
\hline Model & & Sum of Squares & Df & Mean Square & F \\
\hline & Regression & 6.001 & 1 & 6.001 & 11.886 \\
1 & Residual & 4.544 & 9 & .505 & $.007^{\text {a }}$ \\
& Total & 10.545 & 10 & & \\
a. Dependent Variable: Financial performance & & & \\
b. Predictors: (Constant), ratio of nonperforming loans to gross loans & \\
\hline
\end{tabular}

Source: Survey data, 2020.

The F-ratio was 11.886 at 1 degree of freedom which is the variable factor. This represented the effect size of the regression model and the model is significant at $99 \%$ confidence level $(\mathrm{p}=.007 \mathrm{a})$ indicating that profitability can be predicted using non performing loans.

Model summary

The implication of the model was as displayed in the table below;

Table 5. Model Summary.

\begin{tabular}{lllll}
\hline Model & R & R Square & Adjusted R Square & Std. Error of the Estimate \\
\hline 1 & $.754^{\mathrm{a}}$ & .569 & .521 & .71056 \\
\hline
\end{tabular}

Source: Survey data, 2020. 
From the table above, the value of adjusted R-square is 0.521 which indicates that $52.1 \%$ of total variation of profitability is explained collectively by nonperforming loans.

Coefficient analysis

Coefficient analysis from multiple regression analysis is as shown below;

Table 6. Coefficient Analysis.

\begin{tabular}{|c|c|c|c|c|c|c|}
\hline \multirow{2}{*}{\multicolumn{2}{|c|}{ Model }} & \multicolumn{2}{|c|}{ Unstandardized Coefficients } & \multirow{2}{*}{$\begin{array}{l}\text { Standardized Coefficients } \\
\beta \\
\end{array}$} & \multirow{2}{*}{$\mathbf{t}$} & \multirow{2}{*}{ Sig. } \\
\hline & & $\beta$ & Std. Error & & & \\
\hline \multirow{2}{*}{1} & (Constant) & 4.603 & .684 & & 6.730 & .000 \\
\hline & Ratio of nonperforming loans to gross loans & -.985 & .286 & -.754 & -3.448 & .007 \\
\hline
\end{tabular}

Source: Survey data, 2020.

As aforementioned, the model was found to be statistically significant. Further, the regression model can be outlined as follows:

$$
\text { Profit after } \operatorname{Tax}=(4.603)+-.754 \mathrm{X}_{1}+.684
$$

Hypothesis $1\left(\mathrm{H}_{\mathrm{A}} 1\right)$ predicted that non performing loans has significant effect on profitability of the Banking industry. The results in Table 6 indicate that non performing loans have a significant effect on profitability at $p<0.05$. A unit increase in nonperforming loans caused a.754 decrease in profitability of the banking industry. Thus we fail to reject the null hypothesis that non performing loans have a significant effect on profitability of the banking industry. The study is in tandem with the findings of $[21,6,1]$ that nonperforming loans have a negative effect on profitability of the banking industry. The study disagrees with the findings of [28] who found that nonperforming loans has no effect on profitability of the banking industry.

\section{Conclusions}

Non-performing loans has a negative effect on profitability of the banking industry. Upsurge in the rate of nonperforming loans to gross loans reduces the profit after tax of the banking industry. The increase in the proportion of non performing loans is as a result of delayed payments by government agencies and private sector, business stagnation during the prolonged electioneering period in the case of 2018 , and slow uptake of developed houses in the real estate sector. High interest rates and reduced economic activities during the period towards and after the March 2013 general elections led to downgrading of loan accounts by banks, which impacted negatively on the quality of assets. Deployment of enhanced appraisal standards continuously by the financial institutions, write-offs and recoveries by some institutions and enhanced credit underwriting standards applied by financial institutions. Poor credit management and poor management of loan portfolios leads to deterioration of the quality of the bank loan book. Unstable economic times results in higher default rate because borrowers fail to repay their loans due to shrinking purchasing power.

\section{Recommendations}

In order to hedge against upsurge in the rate of non- performing loans, the banking industry should enforce effective regulation, create awareness, and curb unproductive borrowings. There must be multiple level of approval to sanction huge loans. Credit underwriting standards applied by financial institutions should be enhanced. Appraisal standards should be enhanced by the financial institutions. Moreover, there should be transparent mechanism and proper disclosure regulation. Banks and sanctioning officials must be made accountable for the decision. Timely action and communication, proper legal system, cooperation and coordination between different authorities should be upheld at all times. Commercial banks should not fail to disclose nonperforming loans and/ or use provisions for losses on non performing loans for profit smoothening. Banks information on credit applicants should be improved through information sharing. There should be a continuous review of individual exposures in order to monitor loan quality and reduce losses. Loan delinquency must be minimized by Banks at all cost. Prudent credit management and lending practice should be embraced by all financial institutions. There should be appropriate credit policies and adequate supervision by the central bank.

\section{References}

[1] Adeusi, S. O., Kolapo, F. T., \& Aluko, A. O. (2014). Determinants of commercial banks' profitability panel evidence from Nigeria. Internafional Journal of Economics, Commerce and Management, 3 (1), 1-8.

[2] Ahmed, A. (2003). Trends in Profitability of banks in Nigeria: Before and during interest rate deregulation a comparative analysis. NDIC quarterly, 12 (1), 59-83.

[3] Akerlof, G. A. (1970). The market for lemons: quality uncertainty and the market mechanism. Review of financial studies, 17 (2), 405-437.

[4] Akinola, G. (2012). Effect of globalization on performance in the Nigerian Banking Industry. International Journal of Management and Marketing Research, 5 (1), 79-94.

[5] Altman, E. I. (1984). A further empirical investigation of the bankruptcy cost question. The Journal of Finance, 39 (4), 1067-1089.

[6] Azeem, A., \& Amara, A. (2014). Impact of profitability on quantum of nonperforming loans. International Journal of Multidisciplinary Consortium, 1 (1), 1-14. 
[7] Baltagi, B. (2008). Econometric analysis of panel data. $\left(4^{\text {th }}\right.$ Ed.). New Jersey: John Wiley \& Sons.

[8] Brealey, R. A., Myers, S. C., \& Allen, F. (2011). Principles of corporate finance. (10th Ed.). New York: McGraw-Hill.

[9] Central Bank of Kenya. (2001). Bank supervision Annual Report. Retrieved from https://www.centralbank.go.ke.

[10] Central Bank Annual Report. (2018). Annual report and financial statements 2017/2018. Retrieved from https://www.centralbank.go.ke.

[11] Cooper, D. R., Schindler, P. S., \& Sun, J. (2006). Business research methods (Vol. 9). New York: McGraw-Hill Irwin.

[12] Chen, X., Lee, C. W. J., \& Li, J. (2008). Government assisted earnings management in China. Journal of Accounting and Public Policy, 27 (3), 262-274.

[13] Crystal, J. S., Dages, B. G., \& Goldberg, L. S. (2002). Has foreign bank entry led to sounder banks in Latin America? Current Issues in Economics and Finance, 8 (1), 1-6.

[14] De Franco, G., Kothari, S. P., \& Verdi, R. S. (2011). The benefits of financial statement comparability. Journal of Accounting Research, 49 (4), 895- 931.

[15] Fama, E. F. (2012). Efficient capital markets: II. The Journal of Finance, 46 (5), 1575-1617.

[16] Frank, M. Z., \& Goyal, V. K. (2003). Testing the pecking order theory of capital structure. Journal of financial economics, 67 (2), 217-248.

[17] Goudreau, R. E., \& Whitehead, D. D. (1989). FYI Commercial Bank Profitability: Improved In 1988. Economic Review-Federal Reserve Bank of Atlanta, 74 (4), 34 - 41.

[18] Habib, M. A., \& Bruce Johnsen, D. (2000). The private placement of debt and outside equity as an information revelation mechanism. The Review of Financial Studies, 13 (4), 1017-1055.

[19] Hall, G. C., Hutchinson, P. J., \& Michaelas, N. (2004). Determinants of the capital structures of European SMEs. Journal of Business Finance \& Accounting, 31 (5-6), 711-728.

[20] Hancock, D. (1989). Bank profitability, deregulation, and the production of financial. Journal of the Operational Research Society, 47 (8), 980-988.

[21] Kaaya, I., \& Pastory, D. (2013). Credit risk and commercial banks performance in Tanzania: A panel data analysis. Research Journal of Finance and Accounting, 4 (16), 55-62.

[22] Kithinji, A. M. (2011). Credit Risk and Profitability of Commercial Banks in Kenya. Unpublished Masters Thesis, University of Nairobi.

[23] Kiyai, T. K. (2003). Bad debts restructuring techniques and non-performing loans of commercial banks in Kenya. Unpublished PhD Thesis, University of Nairobi.
[24] Kondo, K. (2018). Does branch network size influence positively the management performance of Japanese regional banks? Applied Economics, 50 (56), 6061-6072.

[25] Kothari, C. R. (2004). Research methodology: Methods and techniques. India: New Age International.

[26] Kroszner, R. S., Laeven, L., \& Klingebiel, D. (2007). Banking crises, financial dependence, and growth. Journal of financial Economics, 84 (1), 187-228.

[27] Macharia, J. N. (2012). The relationship between the level of nonperforming Loans and the financial performance of commercial banks in Kenya. Unpublished Masters Thesis, University of Nairobi.

[28] Lind, D. A., Marchal, W. G., \& Wathen, S. A. (2012). Statistical techniques in business \& economics. New York, NY: McGraw-Hill/Irwin.

[29] Mombo, A. C. (2013). The effect of nonperforming loans on the financial performance of deposit taking microfinance institutions in Kenya. Unpublished Masters Thesis, University of Nairobi.

[30] Ogunleye, R. W. (1995). Monetary Policy Influence on Banks' Profitability. NDIC Quarterly, 5 (4), 48-66.

[31] Petersen, M. A., \& Rajan, R. G. (2012). The benefits of lending relationships: Evidence from small business data. The Journal of Finance, 49 (1), 3-37.

[32] Pinegar, J. M., \& Lease, R. C. (2012). The Impact of Preferred-for-Common Exchange Offers on Firm Value. The Journal of Finance, 41 (4), 795-814.

[33] Sabo, B. (2007). An Assessment of the Determinants of the Nigerian Banking Industry Profitability Using Panel Evidence from Nigerian Commercial Banks. Information Manager (The), 7 (2), 14-20.

[34] Sanni, M. R. (2009). Short term effect of the 2006 consolidation on profitability of Nigerian banks. Nigerian Research Journal of Accountancy, 1 (1), 177-188.

[35] Saunders, M., Lewis, P., \&Thornhill, A. (2009). Business research methods. London: Financial Times, Prentice Hall.

[36] Singh, Y. K. (2006). Fundamental of research methodology and statistics. India: New Age International.

[37] Schnabl, G., \& Hoffmann, A. (2008). Monetary policy, vagabonding liquidity and bursting bubbles in new and emerging markets: An over investment view. World Economy, 31 (9), 1226-1252.

[38] Uchendu, O. (1995). Monetary Policy and the Performance of Commercial Banks in Nigeria. Central Bank of Nigeria Economic and Financial Review, 33 (2), 156-170. 